\title{
Conduit margin heating and deformation during the AD 1886 basaltic Plinian eruption at Tarawera volcano, New Zealand
}

\author{
Jenny Schauroth ${ }^{1} \cdot$ Fabian B. Wadsworth ${ }^{1} \cdot$ Ben Kennedy ${ }^{2} \cdot$ Felix W. von Aulock $^{3}$. \\ Yan Lavallée $^{3}$ - David E. Damby ${ }^{1}$. Jérémie Vasseur ${ }^{1} \cdot$ Bettina Scheu $^{1}$. \\ Donald B. Dingwell ${ }^{1}$
}

Received: 12 June 2015 / Accepted: 25 January 2016 / Published online: 13 February 2016

(C) The Author(s) 2016. This article is published with open access at Springerlink.com

\begin{abstract}
During explosive eruptions, a suspension of gas and pyroclasts rises rapidly within a conduit. Here, we have analysed textures preserved in the walls of a pyroclastic feeder dyke of the AD 1886 Tarawera basaltic Plinian fissure eruption. The samples examined consist of basaltic ash and scoria plastered onto a conduit wall of a coherent rhyolite dome and a welded rhyolitic dome breccia. We examine the textural evidence for the response of the wall material, built of $\sim 75$ vol. $\%$ glass and $\sim 25$ vol. $\%$ crystals (pore-free equivalent), to mass movement in the adjacent conduit. In the rhyolitic wall material, we quantify the orientation and aspect ratio of biotite crystals as strain markers of simple shear deformation, and interpret juxtaposed regions of vesiculation and vesicle collapse as evidence of conduit wall heating. Systematic changes occur close to the margin: (1) porosity is highly variable, with areas locally vesiculated or densified, (2) biotite crystals are oriented with their long axis parallel to the margin, (3) the biotites have greater aspect ratios close to the margin and (4)
\end{abstract}

Editorial responsibility: T. Thordarson

Electronic supplementary material The online version of this article (doi:10.1007/s00445-016-1006-7) contains supplementary material, which is available to authorized users.

Jenny Schauroth

jenny.schauroth@min.uni-muenchen.de

1 Department of Earth and Environmental Science, Ludwig-Maximilians-Universität (LMU), Theresienstr. 41, 80333 Munich, Germany

2 Department of Geology, University of Canterbury, Private Bag 4800, Christchurch, New Zealand

3 School of Earth, Ocean and Ecological Science, University of Liverpool, Brownlow Street, Liverpool, UK the biotite crystals are fractured. We interpret the biotite phenocryst deformation to result from crystal fracture, rotation and cleavage-parallel bookcase translation. These textural observations are inferred to indicate mechanical coupling between the hot gas-ash jet and the conduit wall and reheating of wall rock rhyolite. We couple these observations with a simple 1D conductive heating model to show what minimum temperature the conduit wall needs to reach in order to achieve a temperature above the glass transition throughout the texturally-defined deformed zone. We propose that conduit wall heating and resulting deformation influences conduit margin outgassing and may enhance the intensity of such large basaltic eruptions.

Keywords Pyroclastic dyke - Volcanic conduit · Magmarock interaction $\cdot$ Strain localisation $\cdot$ Wall rock heating

\section{Introduction}

Records of explosive basaltic eruptions of Plinian intensities are improving (e.g., Thordarson and Self 2003; Sable et al. 2009; Costantini et al. 2010; Marzoano et al., 2013) and although some authors have proposed eruption mechanisms (e.g., Houghton et al. 2004; Houghton and Gonnermann 2008; Sable et al. 2009; Costantini et al. 2010; Goepfert and Gardner 2010; Kennedy et al. 2010), the mechanics remain debated. Explanations for the exceptional explosivity of basaltic magmas include magma-water interaction (e.g., Houghton et al. 2004), high magma viscosities due to degassing-induced microlite crystallisation or due to cooling of the magma triggered by degassing (Houghton and Gonnermann 2008; Sable et al. 2009; Goepfert and Gardner 2010), critical bubble volumes causing the magma to disrupt (Goepfert and Gardner 2010), high degrees of outgassing 
contributing to higher melt viscosities and lower ascent rates (Houghton et al. 2004), instantaneous drops in the external pressure triggering high decompression rates (Costantini et al. 2010) and a decrease in conduit wall porosity leading to conduit wall sealing (Kennedy et al. 2010). Here, we explore the conduit wall sealing hypothesis further and analyse the textural record of such a process in order to evaluate if it is one possible contributing factor to high explosivity events at basaltic volcanoes.

The most powerful known examples of basaltic Plinian eruptions include the $\sim 60$-ka Fontana Lapilli and the $\sim 2-\mathrm{ka}$ Masaya Triple Layer deposits in Nicaragua, the 122 BC eruption of Etna and the AD 1886 Tarawera eruption in New Zealand (e.g., Houghton et al. 2004; Costantini et al. 2010). A recent example of such intense basaltic behaviour is the 2011 eruption of Grímsvötn in Iceland (e.g., Marzano et al. 2013). The basaltic dykes that feed these eruptions are rarely exposed. The AD 1886 Tarawera fissure eruption, however, is known to have exposed at least 16 basaltic feeder dykes (Nairn and Cole 1981). According to Nairn and Cole (1981), the dykes represent segments of the vent system where the eruption did not become highly explosive. Nevertheless, they provide an opportunity to examine the interaction between pyroclasts and conduit wall rocks during eruption.

Conduit wall properties may influence the behaviour of ascending magma and eruption dynamics (e.g., Stasiuk et al. 1996; Houghton et al. 2004; Rust et al. 2004; Kennedy et al. 2010). Conduit wall porosity is highly variable (Rust et al. 2004; Kennedy et al. 2010) due to interchangeable contribution from fractures, vesicles and cavities. The loss of gas from ascending magma can occur through such permeable structures (Jaupart 1998), reducing gas pressure and thus regulating the explosivity of eruptions (Stasiuk et al. 1996; Castro et al. 2012a, 2014). The presence of glass in the groundmass of conduit wall rocks will modify the wall rock behaviour on heating. Upon sufficient reheating, the glass will soften at the glass transition temperature interval, above which it is a supercooled viscous liquid. Hence, magma can exhibit both brittle and viscous deformation upon eruption (Dingwell and Webb 1989, 1990), healing of fractures (Tuffen et al. 2003; Cordonnier et al. 2012), vesiculation (e.g., Proussevitch and Sahagian 1996) and pore collapse (e.g., Westrich and Eichelberger 1994). As the rheology of bubbly magmas exhibits dependence on bubble content, capillary numbers and magma ascent rates (Manga et al. 1998; Llewellin and Manga 2005), along with temperatures and coupled stresses from the conduit interior, a change in bulk porosity can also lead to varying strain rates (e.g., Russell and Quane 2005) in the wall rock. As a result, the mechanical response (brittle vs. ductile) of the conduit lining to magma motion in the conduit is dependent on the magmatic overpressure triggering tensile failure (e.g., Heiken et al. 1988), and on the conduit wall porosity influencing the tensile strength. This has implications for the eruption style (Rust et al. 2004) and may influence parameters such as the threshold and depth of fragmentation (Kennedy et al. 2005).

Kennedy et al. (2010) postulated, based on experiments, that conduit wall softening via heating by the magma and potential decrease in wall rock permeability eventually yields a closed degassing system on the timescale of the 1886 Tarawera eruption. Here, we examine and discuss caveats to this conclusion with reference to the high along-fissure variability in eruption style during the AD 1886 event at Tarawera, while providing evidence that reheating occurred in the conduit margin and viscous shearing of conduit wall rock from interaction with gas-pyroclastic jets.

\section{Background: dykes feeding the AD 1886 tarawera volcano eruption}

The Tarawera Volcanic Complex is part of the southern Okataina Volcanic Centre in the Taupo Volcanic Zone and it consists of 11 rhyolite domes and associated pyroclastic deposits (Cole 1970a). The youngest four domes-Crater, Ruawahia, Tarawera and Wahanga dome (from oldest to youngest; Fig. 1)—were emplaced in the $\sim$ AD 1315 Kaharoa eruption episodes (Nairn et al. 2004). The most recent eruption from the Tarawera Volcanic complex was a basaltic Plinian eruption that took place on 10 June AD 1886. It began in the northeast within the Wahanga dome and propagated $\sim 17 \mathrm{~km}$ along a fissure to the southwest, forming $\geq 100 \mathrm{~m}$ deep craters through the existing dome complex (Cole 1970a; Walker et al. 1984; Houghton et al. 2004; Sable et al. 2006, 2009; Carey et al. 2007). The eruption was fed by several en echelon dykes (Nairn and Cole 1981) and disrupted a large pre-existing geothermal system at the southwest end of the fissure (Houghton et al. 2004). The event lasted $\sim 5 \mathrm{~h}$ (Nairn and Cole 1981; Houghton et al. 2004) during which $\sim 0.8 \mathrm{~km}^{3}$ of chemically uniform, high-alumina basaltic magma was erupted (Houghton et al. 2004) at an estimated temperature ranging from 1,200 to $800{ }^{\circ} \mathrm{C}$ (temperature estimates based on experimental validation of preserved textures; Kennedy et al. 2010).

A conceptual model of the eruption, assembled from multiscale analyses of proximal deposits, has outlined the following eruption stages (detailed in: Houghton et al. 2004; Sable et al. 2006; Carey et al. 2007): (1) An initial phase beginning with phreatomagmatic eruptions from magma-groundwater interactions and vent-opening explosions. The opening of vents led to more rapid ascent of vesiculating magma, a change in fragmentation depth and a shift to purely magmatic eruption. (2) Peak Plinian intensity was achieved at discrete dischargefocus sites along the vent system. (3) A waning stage of Plinian activity, followed by a discharge of actively vesiculating magma and accumulation of partially outgassed magma in 
Fig. 1 A digital elevation model showing the position and orientation of the AD 1886 basaltic fissure in relation to the older rhyolitic domes which the eruption intersects. Note that the fissure does not pass through the centre of Wahanga dome. The position of the dyke here studied is indicated by a star (see key for details). Hashed area shows where breccia of the Wahanga dome is exposed in the studied field area. Inset: the position of Fig. 1 in the wider Taupo Volcanic Zone in the North Island of New Zealand. (A detailed map of all dyke exposures is in Nairn and Cole (1981))

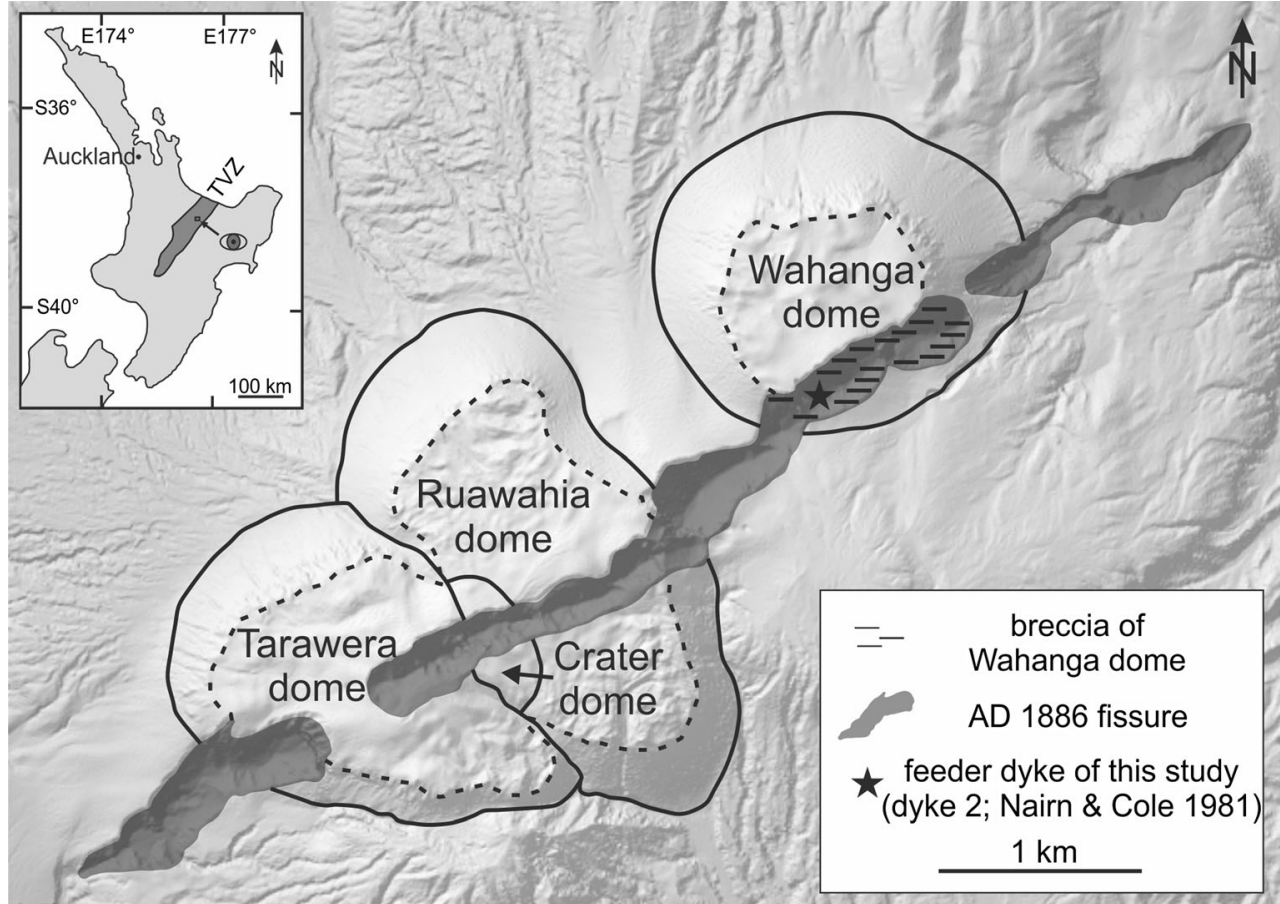

the shallow plumbing system. These processes reduced the effective radius of the conduit and led to an increase in depth of fragmentation. (4) A further increased depth of fragmentation along with waning magma flux led to renewed interaction with groundwater, removing much of the partially-outgassed magma.

The eruption is believed to have come to an end as the overpressure in the magma source dropped and magmawater interaction was no longer sufficiently extensive to sustain phreatomagmatic fragmentation. On the basis of mapping, Nairn and Cole (1981) have identified en echelon basaltic dykes along the AD 1886 Tarawera rift, which are now well-exposed in the base of the preserved eruption fissure. They were filled with basaltic scoria bombs, lapilli and ash after the eruption. Here, we describe one such dyke in the northeastern part of the fissure (dyke 2 from Nairn and Cole 1981). It varies between 4 and $6 \mathrm{~m}$ in width and is exposed at the surface of the Wahanga dome over a distance of $6 \mathrm{~m}$ from above and over $10 \mathrm{~m}$ height in cross section (Fig. 2). The dyke is entirely clastogenic. Close to the dyke margins the pyroclastic material within the dyke is dominated by ash sized particles that are finely laminated parallel to the margin on the scale of hundreds of micrometres to tens of millimetres (Fig. 3d-e). The rest of the dyke is thought to be backfilled with pyroclasts from the final phase of the AD 1886 eruption (Nairn and Cole 1981; Walker et al. 1984; Carey et al. 2007). The clast sizes grade into coarse bombs at $>50 \mathrm{~cm}$ from the margin (Fig. 2a). The dyke is hosted by the AD 1315 Wahanga dome-forming rhyolite (Figs. 1 and 2), which is composed of clasts from 0.5 to $100 \mathrm{~cm}$ in diameter, cemented by indurated rhyolitic matrix fines (Fig. 2). The rhyolite is highly vesicular and brecciated near the dyke but intact in the walls of the dome that are exposed in the Tarawera fissure margins. At this site, there is no crystal alignment apparent in the rhyolite (Ashwell et al. 2015).

We undertook an in-field assessment of the lithologies exposed at the dyke to confirm the broad-scale features described in Kennedy et al. (2010) and Nairn and Cole (1981). Namely that there is a consistent deformed rind of marginal wall rock in contact with the outer surface of the dyke. This coherent rind is texturally homogeneous along strike of the dyke and implies heat transfer between basalt and rhyolite, at least on the scale of the outcrop (Kennedy et al. 2010). According to Nairn and Cole (1981) this rind is the dense baked margins of the rhyolite in contact with the dyke that is polished and striated. Similarly, we examined blocks of the rhyolite far from the marginal dyke contact (>10 m) to assess their variability and, while there are clast to clast differences, these samples are always texturally distinct from the deformed rind at the margin.

From the dyke margins, we collected a sample of (1) a locally representative $\sim 20 \mathrm{~cm}$ diameter rhyolitic single clast (Figs. 2b and 3a) and (2) a clastic rhyolitic sample, which consists of several smaller clasts agglutinated by finergrained rhyolite (Figs. $2 \mathrm{~b}$ and $3 \mathrm{~b}-\mathrm{c}$ ). Both samples exhibit a distinct $0.1-3 \mathrm{~cm}$ thick and deformed rind at the rhyolite wall rock to basalt dyke interface representing syn-eruption melting of the host rhyolite and near-simultaneous sintering of some of the basaltic material (Fig. 3). For comparison, we also sampled $10-50 \mathrm{~cm}$ rhyolite dome breccia clasts with variable 
Fig. 2 Outcrops relevant to this study. a A photograph showing the pyroclastic feeder dyke and the surrounding breccia of the Wahanga dome. b A photograph showing the marginal contact between the AD 1886 basaltic dyke and the Wahanga dome rhyolite on the SW side of the feeder dyke. Sample locations of the single clast sample and the clastic sample are highlighted
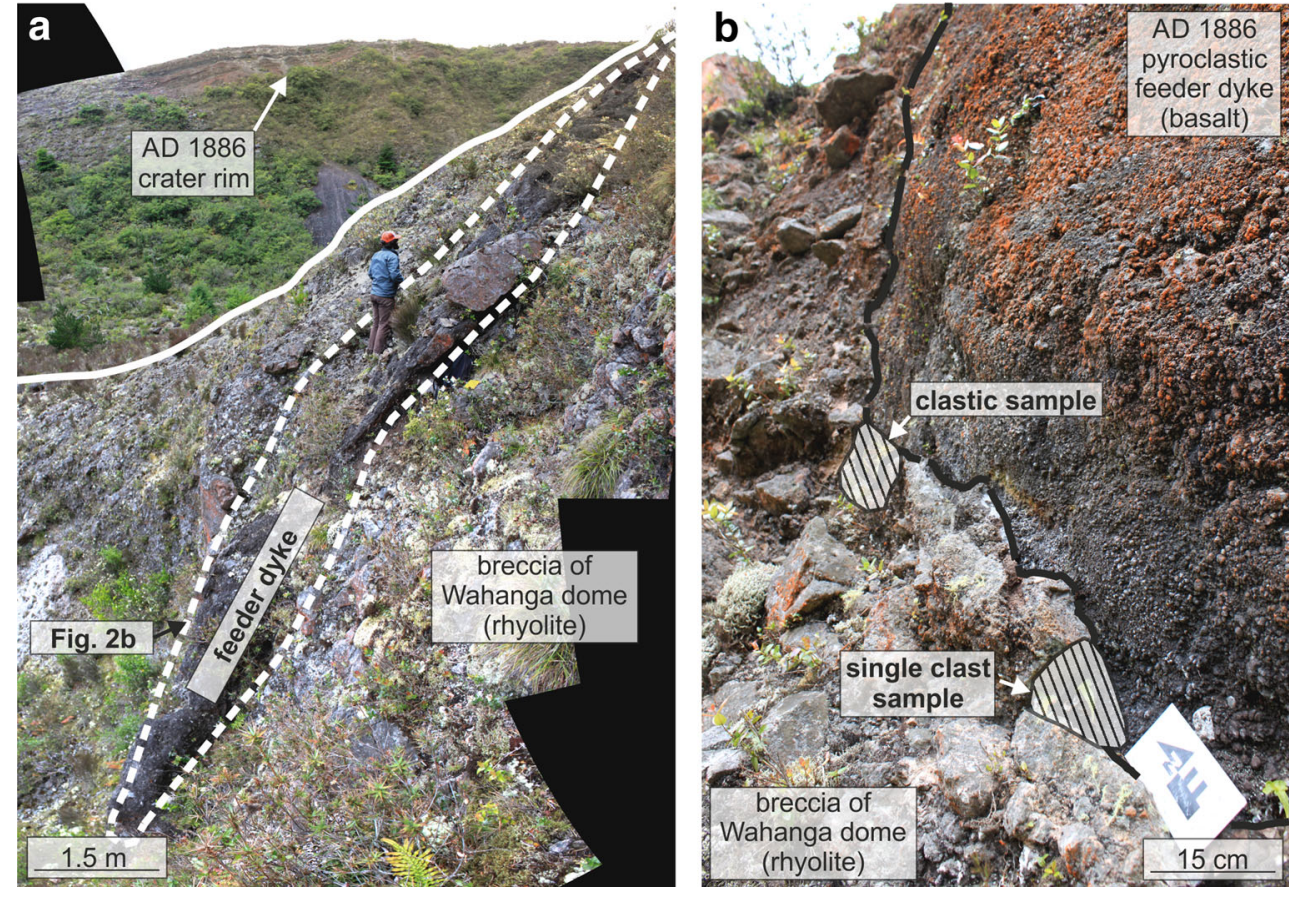

internal textures from the rhyolitic material at distance $(>10 \mathrm{~m}$ from the conduit margin) to the AD 1886 feeder dyke. We limit our observations to the marginal contact between the basalt and the rhyolite, which represent syn-eruptive deposits passing by and sintering to the marginal rhyolite.

\section{Micro-scale textures}

Below we describe the textures of (1) a rhyolitic breccia clast situated at $10 \mathrm{~m}$ from the basaltic dyke margin, taken to represent the original rhyolitic textures, unmodified by the 1886 eruption (distal rhyolite; Figs. $4 \mathrm{a}-\mathrm{d}$ and $5 \mathrm{a}-\mathrm{d}$ ) and (2) two oriented clasts of rhyolitic breccia at the margin of the $\mathrm{AD}$ 1886 basaltic pyroclastic dyke (proximal rhyolite; Figs. 3, $4 \mathrm{e}-\mathrm{j}$ and $5 \mathrm{e}-\mathrm{h}$ ). Both rhyolitic breccias are from a flow lobe within the Wahanga dome. Thin sections of the oriented clasts were cut perpendicular to the strike of the dyke margin and parallel to the vertical flow direction, and our description of this strain localisation phenomenon focuses on vesicle textures and biotite deformation within a few millimetres of the dyke margin.

\section{Distal rhyolite wall rock}

The porosity of the distal rhyolite is typically $28-30$ vol.\% (Kennedy et al. 2010) and is predominantly connected (Ashwell et al. 2015). Vesicle sizes vary over a large range from micron- to millimetre-sized and vesicle shapes are spherical to convolute and contorted, recording locally differential amounts of shear strain. There are domains of hundreds of microns to millimetres of relatively low ( 5 vol.\%) vs. relatively high vesicularity ( 50 vol.\%; Figs. $4 \mathrm{a}-\mathrm{d}$ and $5 \mathrm{a}-\mathrm{d})$. In the low-vesicularity regions, the vesicles are preferentially orientated parallel to crystal margins, and vary from near circular to highly elongated with aspect ratios up to 50 in $2 \mathrm{D}$ cross-section (Fig. $4 \mathrm{a}-\mathrm{d}$ ). In the high-vesicularity regions the vesicles are more convolute, i.e. more tortuous (relative to those observed in the lowvesicularity regions), and the thin vesicle walls are contorted, such that they intrude neighbouring vesicles (Fig. 4a-d). With increasing vesicle size, the vesicle geometry gets more complex.

The mineralogy of the distal rhyolite is dominated by plagioclase, quartz and biotite phenocrysts with minor components of opaque minerals, orthopyroxene, hornblende, apatite and zircon (Richnow 1999). The crystal content is 2325 vol.\% in the vesicle-free rock (Cole 1970b; Richnow 1999), and glass content approximates 75 vol.\%. The plagioclase phenocrysts are typically euhedral to subhedral and fractured (Fig. $5 \mathrm{c}$ ). The quartz phenocrysts vary in size from 0.8 to $1.6 \mathrm{~mm}$, and they feature closed fractures (i.e. the counterparts are adjacent to each other; Figs. $4 \mathrm{a}-\mathrm{b}$ and $5 \mathrm{a}-\mathrm{b})$. The biotite phenocrysts are $<0.5 \mathrm{~mm}$, euhedral to subhedral and commonly fractured (Figs. $4 \mathrm{a}$ and $5 \mathrm{~b}$ ). Despite the fractures, the individual pieces of the crystal remain contiguous and show no apparent bending. Furthermore, the phenocrysts do not exhibit preferential orientation on the observed scale. See Electronic supplementary material (ESM) Fig. S2 for measurements of the groundmass glass of the distal rhyolite. 

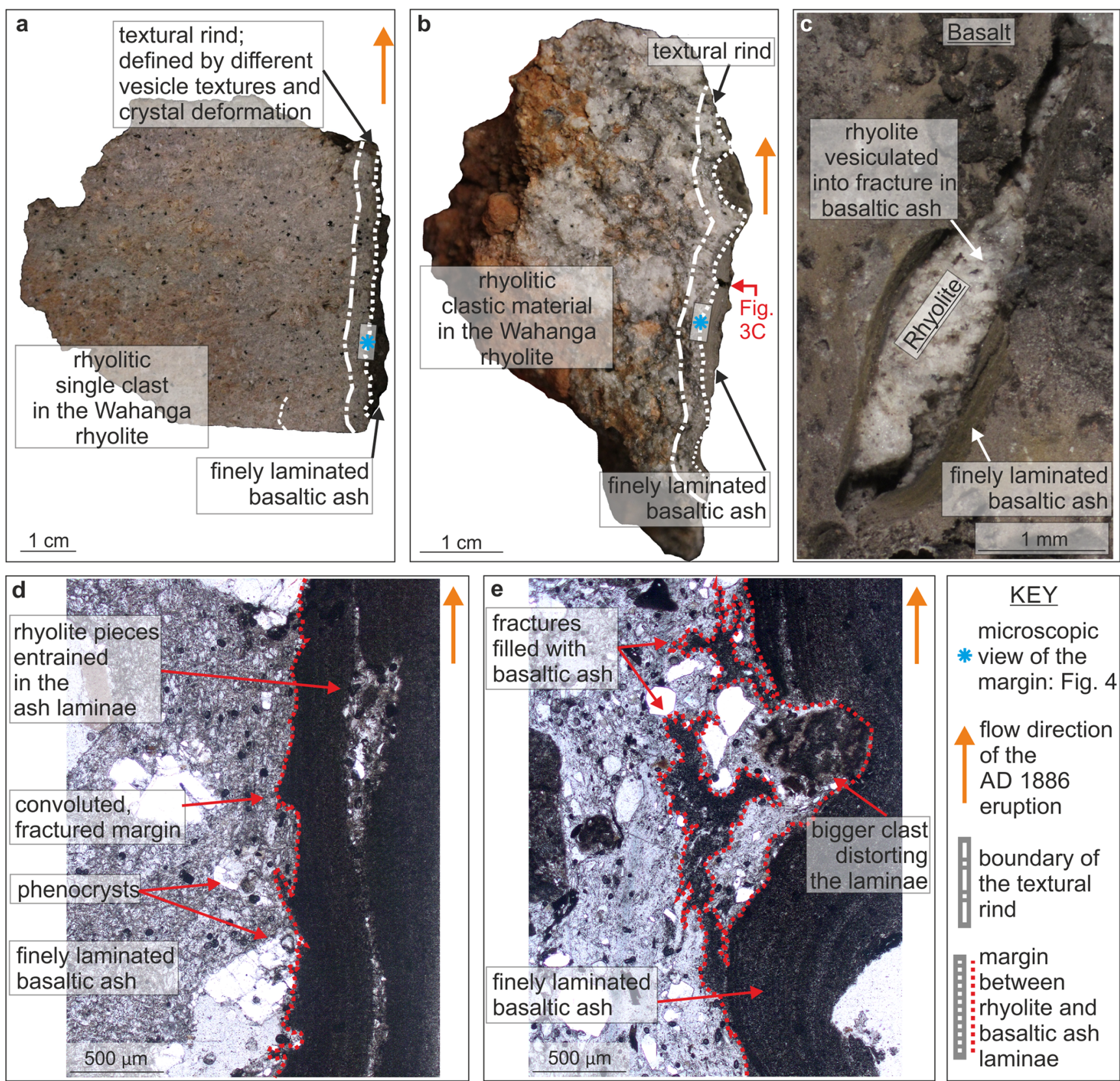

Fig. 3 a Photograph of the single clast sample in contact with the finely laminated basaltic ash. The textural rind is highlighted. b Photograph of the indurated clastic rhyolite in contact with the feeder dyke margin featuring sintered basalt. The textural rind refers to the deformed domain at the marginal contact. c A close up of the sample in Fig. 3b of the dyke to rhyolite interface showing a crack in the sintered, finely laminated basalt and the vesiculated rhyolite exposed beneath. d

\section{Proximal rhyolite wall rock}

The contact of the rhyolitic wall rock and the basaltic dyke (Figs. 3, $4 \mathrm{e}-\mathrm{j}$ and $5 \mathrm{e}-\mathrm{h}$ ) is tortuous and disrupted, with fractures that are locally filled with basaltic ash, both parallel and perpendicular to the margin in the rhyolite wall rock (Fig. 3de). Pieces of rhyolite are entrained in the basaltic ash laminae (Fig. 3d). There is a $\sim 2$-mm wide rhyolitic rind at the interface
Photomicrograph of the single clast sample and the adjacent basaltic ash. Domains of rhyolite are embedded in the basaltic ash. Note the highly convoluted and fractured margin. e Photomicrograph of the interface between clastic rhyolite and the laminated basaltic ash. The rhyolite contains fractures filled by basaltic ash. The contact between the two lithologies is convoluted and fractured and distorted by a bigger clast. The flow direction of the dyke material is indicated

between the dyke and the host rock, which can be distinguished from the rhyolite wall rock by distinct vesicle textures and increased incidence and magnitude of crystal deformation (Figs. $3 \mathrm{c}-\mathrm{e}$ and $4 \mathrm{e}-\mathrm{j}, 5 \mathrm{e}-\mathrm{h}$ ). The rind features background vesicle textures broadly similar to those observed in the distal rhyolite, which are overprinted by a population of near-spherical, simple vesicles with well-defined vesicle walls (Figs. 4e$\mathrm{j}$ and $5 \mathrm{e}-\mathrm{h}$ ). Such vesicle textures are not present in the 
section of proximal rhyolite contact with AD 1886 basaltic ash; sectioned perpendicular to conduit margin and parallel to flow direction (macroscopic view of margin: Fig. 3a \& 3b)

flow direction of the AD 1886 eruption
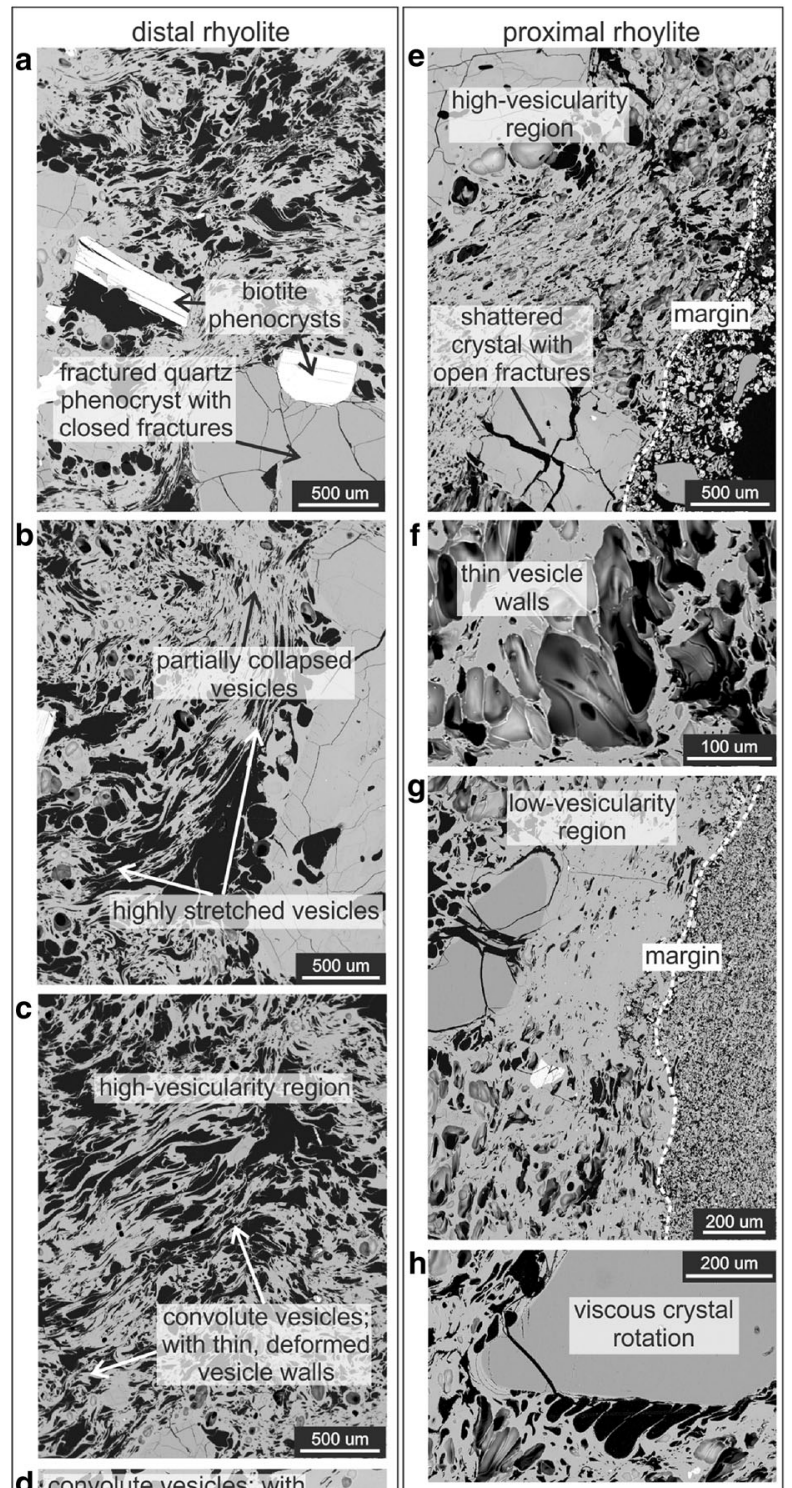

d Convolute vesicles; with
deformed vesicle walls
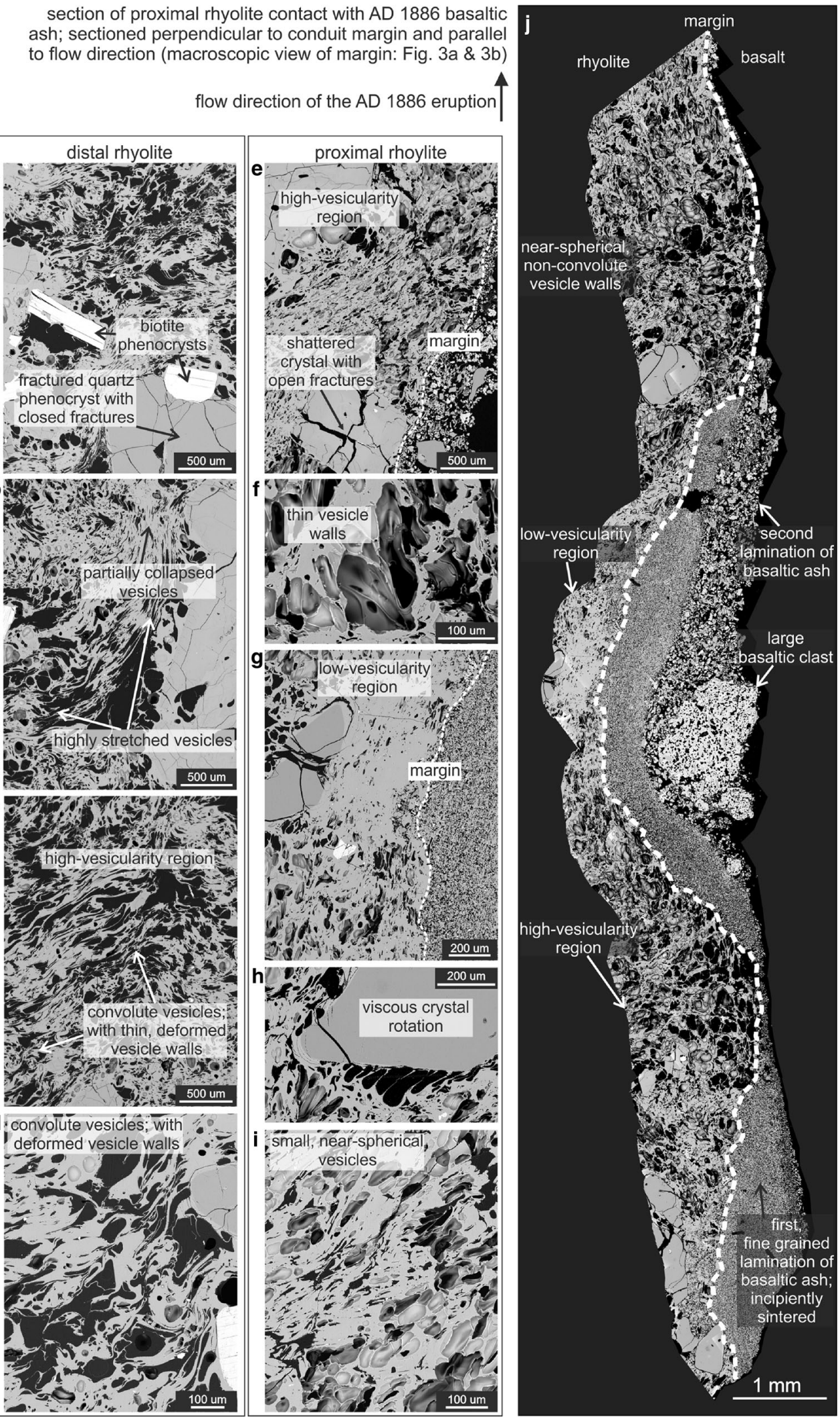

unmodified part of the proximal rhyolite, nor in the distal rhyolite (Figs. 4a-d and $5 \mathrm{a}-\mathrm{d}$ ). These regions of spherical vesicularity are coincident with inflated fractures preserved in the adhered basaltic granular laminae (Fig. 3c). 
4 Fig. 4 a-d Textures in the distal rhyolite shown in representative backscatter electron micrographs. a Fractured quartz phenocrysts with closed fractures. Biotite crystals show intact cleavage. b Vesicles range from partially collapsed to highly stretched and contorted. c Highvesicularity region with convolute vesicles which feature thin and deformed vesicle walls. d Convolute vesicles with deformed walls. e-i Textures in the proximal rhyolite (single clast and clastic material) shown in representative backscatter electron micrographs. e High-vesicularity region featuring a population of small, near-spherical vesicles. Crystals at the dyke interface generally have open fractures. $\mathbf{f}$ The vesicles in the textural rind have well-defined, thin walls. $g$ Low-vesicularity region between the dyke interface and a fractured phenocryst. $\mathbf{h}$ Larger $(\sim 0.1-$ $0.2 \mathrm{~mm}$ ) vesicles with preferential orientation of elongation in the wake of crystal rotation in the reheated rind. i Small and near-spherical vesicles in the rind stand in contrast to large and convolute vesicles in the distal rhyolite. $\mathbf{j}$ An overview section of the proximal rhyolite in contact with the AD 1886 basaltic ash; the rhyolite shows low- and high-vesicularity regions; two laminations of fine basaltic ash are present, disturbed by a big basaltic clast. All photos are taken perpendicular to the conduit margin and parallel to the flow direction of the AD 1886 eruption

The rind of the proximal rhyolite also hosts regions of lowand high-vesicularity, which are significantly larger in extent and with greater variation in vesicle size than any regions observed in the distal rhyolite. Some low-vesicularity regions are located where larger clasts of basalt are present very close to the margin and where the contact protrudes into the rhyolite (Fig. 4j). However, this is a rare feature. The vesicles are less deformed in regions of low-vesicularity relative to those of high-vesicularity regions, ranging from spherical to elongated with aspect ratios $<10$ in the latter. In at least one location at the edge of a 0.5 - to 1 -mm quartz phenocryst, large $\sim 0.1$-to $0.2-\mathrm{mm}$ vesicles exhibit preferential orientation of elongation at a common angle to the crystal edge (Fig. 4h), implying rotation of the crystal in a viscous melt. See ESM Fig. S2 for measurements of oxide distributions in the textural rind.

The mineralogy of the rind of the proximal rhyolite is indistinguishable from that of the distal rhyolite. However, the shattered quartz and plagioclase phenocrysts in the rind feature open fractures, in contrast to closed fractures in the distal rhyolite (Figs. 4e, g and 5f). In addition, the biotite phenocrysts, described below, are deformed internally (Figs. 6 and $7 \mathrm{a}-\mathrm{b})$.

\section{The biotite phenocrysts in the distal and proximal rhyolite}

In the distal rhyolite, the biotite phenocrysts are euhedral, tabular and exhibit pristine basal cleavage (Fig. 7c) as demonstrated by Richnow (1999) and Ashwell (2013). Broken

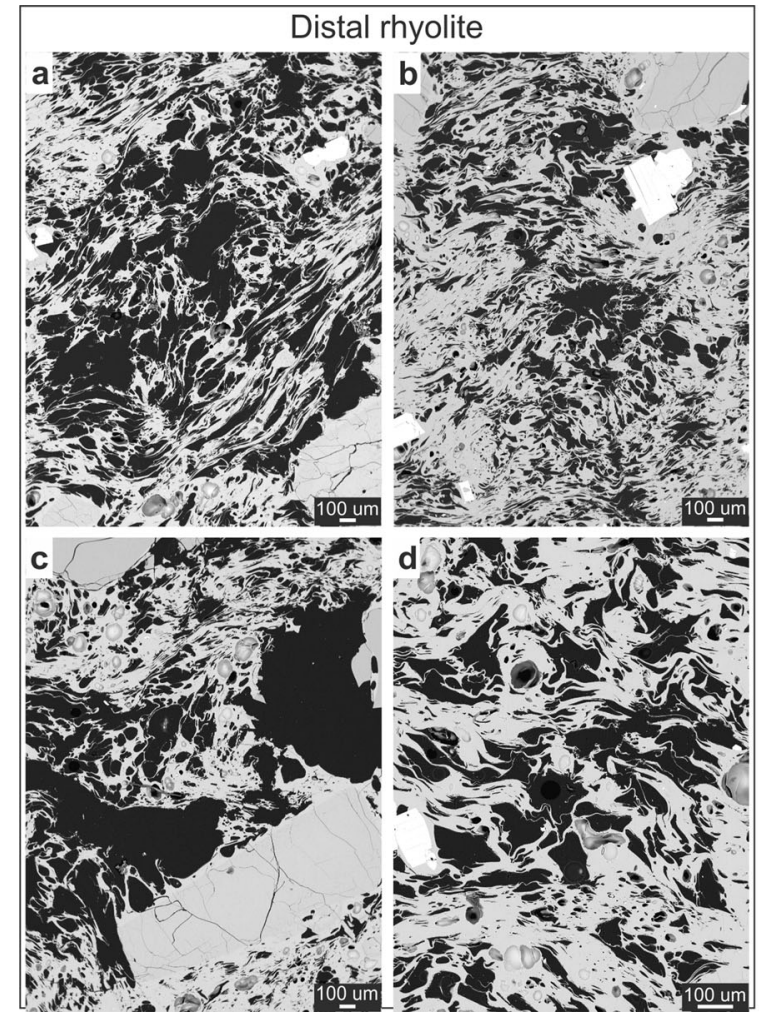

Fig. 5 Comparison of the distal and proximal textures. a-d SEM images of the distal rhyolite. a Large, highly convoluted and stretched vesicles dominate the distal rhyolite. b A set of high- and low-vesicularity regions with intact phenocrysts. c Phenocrysts are fractured. d Vesicles are contorted. $\mathbf{e}-\mathbf{h}$ SEM images of the proximal rhyolite. e Cleaved mica

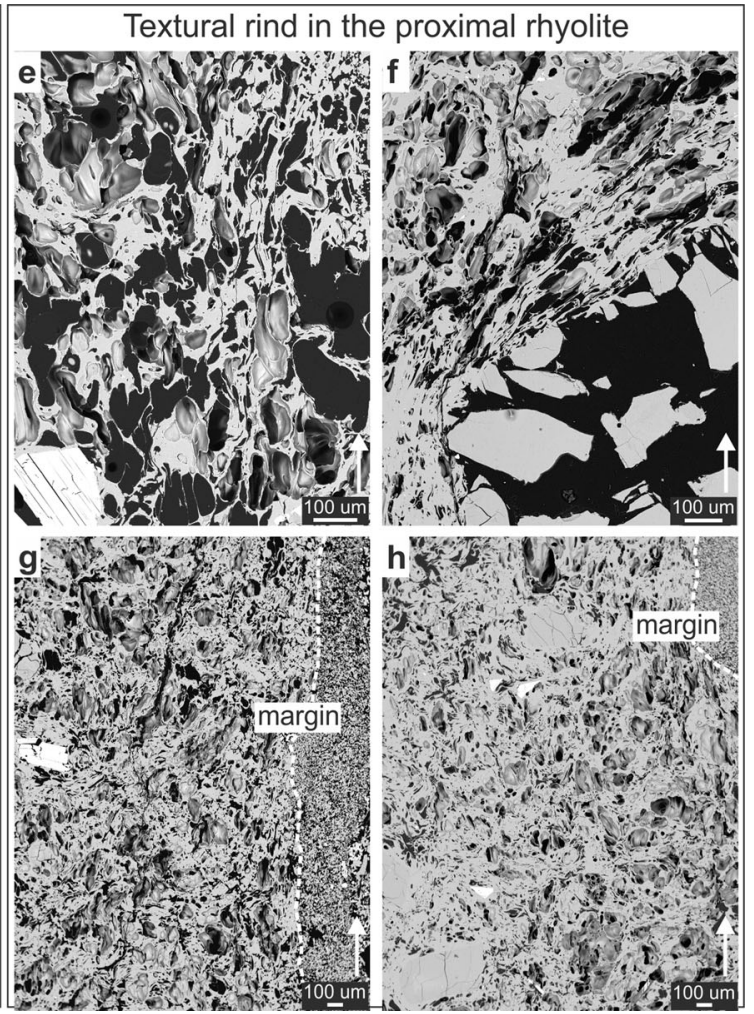

crystal in highly vesicular rhyolite. f Phenocryst in the rind are shattered and exhibit open fractures. $\mathbf{g}-\mathbf{h}$ The textural rind is dominated by smallsized, near-spherical vesicles with well-defined vesicles walls population of smaller, spherical vesicles overprinting the distal textures. The dyke margin is indicated 
Fig. 6 a-d The different deformation textures of biotite phenocrysts in the proximal rhyolite at decreasing distance $(x)$ from the margin. Distance and direction to the margin are indicated by arrows; flow direction is perpendicular to the distance arrow and from left to right. a At a distance of $1.3 \mathrm{~mm}$, first cracks are observed in the biotites. Pieces of the crystal remain contiguous. b At a distance of $0.9 \mathrm{~mm}$, the cleavage is split by vesiculation of the groundmass glass. c At a distance of $0.6 \mathrm{~mm}$, the phenocryst is pervasively fractured perpendicular to the cleavage and the mechanism is purely brittle. Bookshelf-like displacement is apparent. d At a distance of 0.2$\mathrm{mm}$ single crystal fragments are translated and the cleavage is bent
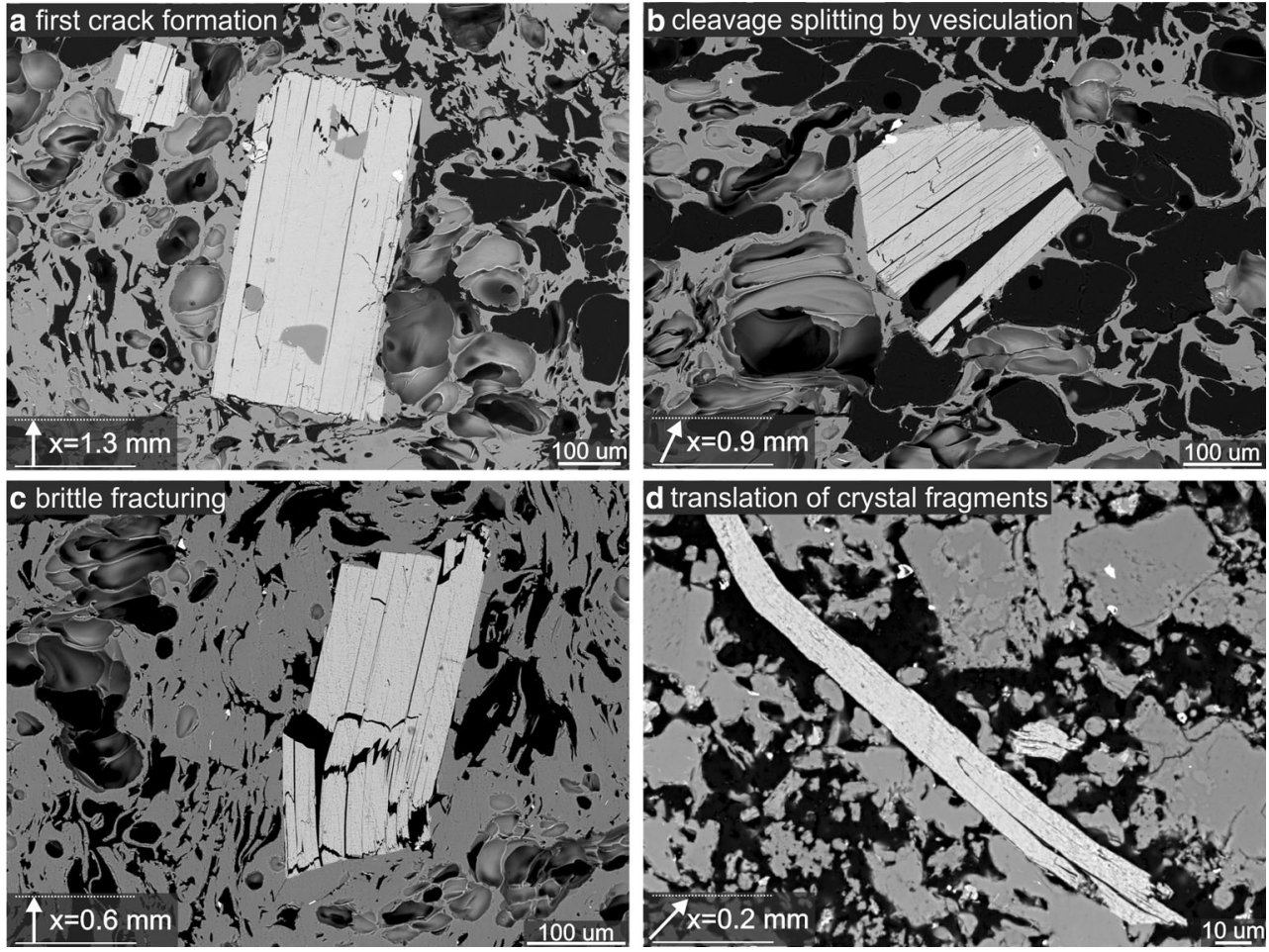

crystals, which can be attributed to flow-induced stresses during dome growth (Allen and McPhie 2003) do not feature open fractures, the individual pieces are contiguous (Figs. $4 \mathrm{a}-\mathrm{b}$ and $5 \mathrm{a}-\mathrm{c}$ ).

The biotites in the proximal rhyolite are different. Within the first few millimetres of the contact with the basalt, the biotite phenocrysts are deformed and biotite fragments are displaced (Figs. 6 and $7 \mathrm{a}-\mathrm{b}$ ). In the $\sim 2-\mathrm{mm}$ thick rhyolite rind, biotite crystals dominantly exhibit brittle fractures and bookcase-style deformation along the basal cleavage planes (Figs. 6 and $7 \mathrm{a}-\mathrm{b}$ ). In the outermost $1 \mathrm{~mm}$, the biotites are highly fractured and cleaved, and the cleavage planes vary, exhibiting undulose extinction (Figs. 6b-d and 7a). Where some minor bending of the crystal hast taken place, intracrystalline misorientation of the cleavage (in the 2D thin section plane) never exceeds $10^{\circ}-15^{\circ}$. However, edge-to-edge fracturing and dislodging of biotite phenocrysts can result in subsequent rotation of one or both of the biotite pieces, creating an apparent angle that can exceed $15^{\circ}$.

The biotite phenocrysts in the single clast sample from the proximal rhyolite have been cleaved and in some instances the crystals are split along the cleavage planes with a measurable separation of the segments on either side of the plane. Each high-aspect-ratio-crystal fragment has been translated parallel to the margin resulting in en echelon features (Fig. 7a). This texture is absent in the clastic sample of the proximal rhyolite. Phenocrysts with their cleavage parallel to the margin are generally deformed by bookshelf-like displacements or separated along their cleavage planes (Fig. 7) whereas phenocrysts with their cleavage normal to the margin are fractured and show a large variation in basal cleavage orientation within a single crystal (Fig. 7).

The distal rhyolite biotites have aspect ratios of 1.0-5.6 with a mean of 1.9 and a standard deviation from the mean of 1.0 (grey shaded region Fig. 8a; Table S1). The proximal rhyolite shows similar biotite aspect ratios at $>2 \mathrm{~mm}$ from the margin with a mean aspect ratio of 2.5 and a standard deviation of 1.8 (Fig. 8a; Table S1). However, at $<2 \mathrm{~mm}$ of the margin, the aspect ratio of biotites in the proximal rhyolite increases in a non-linear fashion to maxima of 31.6 (single clast sample) and 52.0 (clastic sample) respectively, with mean values of 6.7 and 8.5 and standard deviations of 6.4 and 8.8 (Fig. 8a; Table S1). The maximum visible offset from the first to the last piece of a biotite phenocryst is $1.12 \mathrm{~mm}$. The longest piece of that margin-parallel biotite phenocryst is $0.36 \mathrm{~mm}$, which we take to be the approximate undeformed length, $L_{0}$. Strain is $\left(L-L_{0}\right) / L_{0}$, where $L$ is the undeformed length plus the maximum offset distance, which is 3.1 for this deformed biotite.

In the proximal rhyolite, at distances $<1 \mathrm{~mm}$ from the margin with the basaltic feeder dyke, there is an increase in biotite phenocrysts with low $\theta$ values ( $\theta$ is defined as the angle between the long axis of a biotite phenocryst and the conduit margin; Figs. 8b-c; Table S1). $\theta$ values in the distal rhyolite were measured to an arbitrary but fixed reference line, representing the main direction of the margin (the measurement orientation was adjusted to the margin orientation). Only crystals with their $c$ axis parallel to the plane of section are 


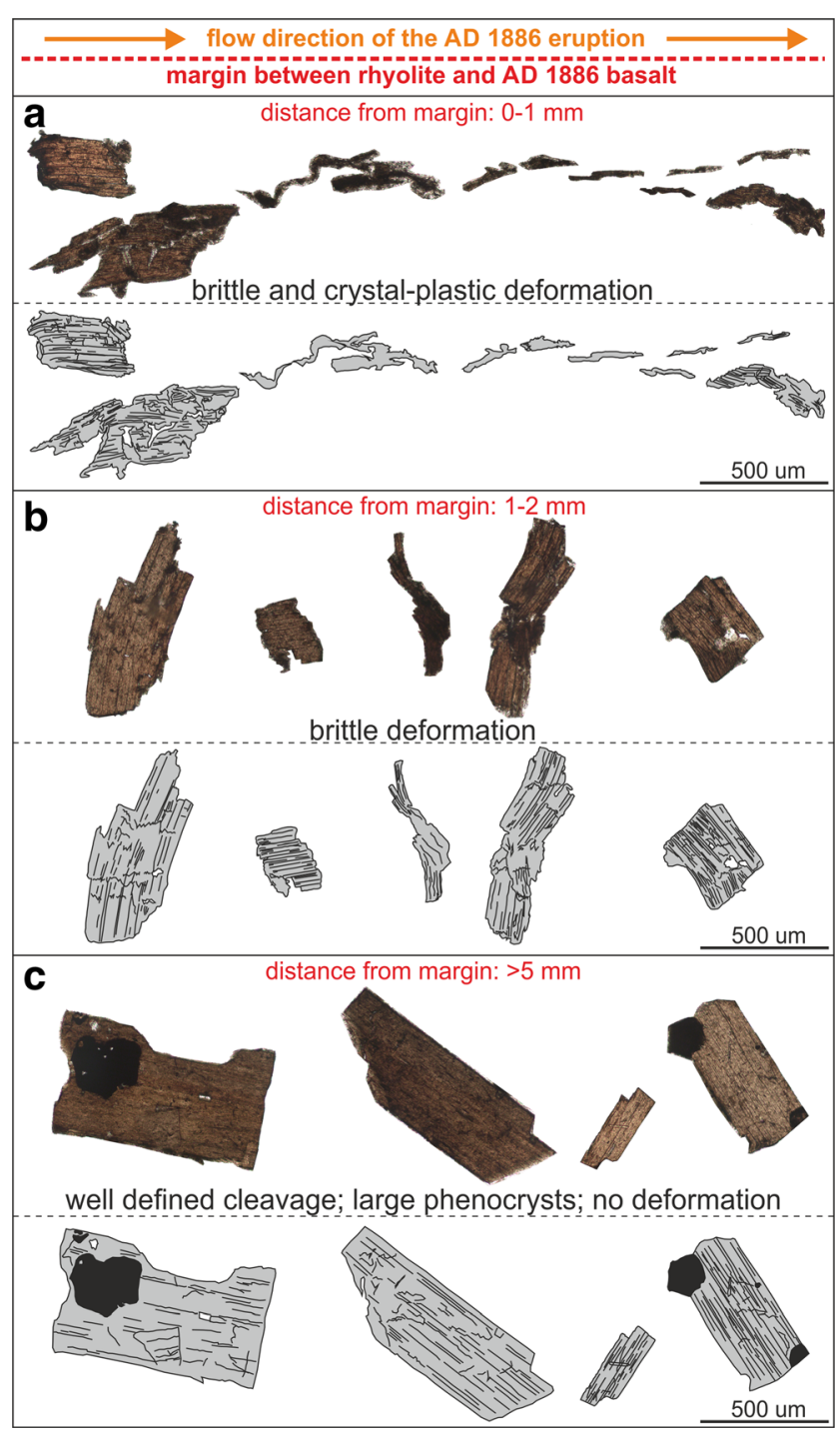

Fig. 7 The variability of representative biotite textures in the textural rind in contact with the basalt feeder dyke (1-2 mm) compared with those from the distal rhyolite $(>5 \mathrm{~mm})$. Discrete crystals in this catalogue are to scale, but the inter-crystal distances are not. a At a distance of $0-1 \mathrm{~mm}$ from the margin, the deformation mechanism is crystal-plastic as well as brittle. The phenocrysts are deformed in a bookshelf-like fashion and single crystal fragments are separated and translated parallel to the margin, resulting in en echelon features. $\mathbf{b}$ At a distance of 1-2 $\mathrm{mm}$ from the margin, bookshelf-like displacements are apparent. Biotites with their cleavage oriented perpendicular to the margin, are deformed by crosscleavage fracturing. The deformation mechanism is purely brittle. $\mathbf{c}$ At a distance of $>5 \mathrm{~mm}$ from the margin, the crystals exhibit pristine cleavage and do not show similar deformation features compared to those crystals in the textural rind. The crystals lack cross-cleavage fractures and displacement of single fragments

included in this assessment. The distal rhyolite biotites have a mean $\theta$ of $44^{\circ}$ with a standard deviation of $22^{\circ}$ (grey-shaded region; Fig. 8b; Table S1). The proximal rhyolite biotites in both samples at distance $>1 \mathrm{~mm}$ from the rhyolite-dyke interface have a mean of $49^{\circ}$ with a standard deviation of $8^{\circ}$ (Table S1). However, at distances $<1 \mathrm{~mm}$ from the interface, the mean value of $\theta$ decreases to $24^{\circ}$ with a standard deviation of $13^{\circ}$ (Table S1). The relative frequency of angles $<10^{\circ}$ is significantly higher in both samples from the proximal compared to that of the distal rhyolite (Fig. 8c). Despite this evidence for physical modification of the biotites in the rind closest to the rhyolite-basalt interface, there is no sign of chemical modification in these biotite crystals (the compositional variability of biotites in the proximal and distal rhyolite in a ternary AFM diagram determined by EMPA is shown in ESM Fig. S1).

\section{The feasibility of reheating a conduit margin: a 1D solution to the heat equation}

Diffusion of heat in a medium can be cast in one dimension and in Cartesian coordinates using

$\frac{\partial T}{\partial t}=\frac{\partial}{\partial x}\left(D \frac{\partial T}{\partial x}\right)$

where $T$ is the temperature, $t$ is the time after the onset of diffusion, $x$ the distance from the margin, and $D$ the thermal diffusivity in the medium. Here, we consider pure heat conduction through a homogeneous rhyolitic country rock. The thermal diffusivity in rhyolitic material (glass or liquid) is a function of temperature (Bagdassarov and Dingwell 1994) and can be approximated by

$D=D_{0} \exp (\alpha T)$,

if $D_{0}$ is an extrapolated diffusivity at $T=0$ and $\alpha$ is a constant. We use $D_{0}=3.66 \cdot 10^{-7} \mathrm{~m}^{2} \cdot \mathrm{s}^{-1}$ and $\alpha=1.24 \cdot 10^{-3} \mathrm{~K}^{-1}$ where the values of $T$ are given in degree Celsius and not kelvin (see ESM for the relevant calibration). For a vesicular rhyolite, we scale the diffusivity calculated by Eq. 2 with the bulk porosity, following Connor et al. (1997), such that:

$D=\frac{k}{\rho C(1-\phi)+\rho^{\prime} C^{\prime} \phi}$,

where $k$ is the bulk thermal conductivity, $\rho$ and $\rho^{\prime}$ are the density of the solid and pore fluid, respectively. $C$ and $C^{\prime}$ are the specific heat capacity of the solid and pore fluid, respectively, and $\phi$ is the bulk porosity (expressed as a volume fraction). The thermal conductivity can also be scaled with porosity using the empirical model by Bagdassarov and Dingwell (1994) which relates $k$ to its pore-free value $k_{0}$ via

$k=k_{0}\left(\frac{1-\phi}{1+\phi}\right)$,

For $\phi=0.5, D_{0}=1.626 \cdot 10^{-7} \mathrm{~m}^{2} \cdot \mathrm{s}^{-1}$ and $\alpha$ is unchanged. We use typical density and heat capacity values for rhyolite 
Fig. 8 a The variability of aspect ratios of biotite in the clastic material and the single clast sample as a function of distance from the dyke to rhyolite interface compared to the aspect ratios of biotite in the distal rhyolite. Note the increase in the aspect ratios at a distance from the margin of $\sim 2 \mathrm{~mm}$. The sketch shows how the aspect ratio data was obtained. The extent of the textural rind, is indicated by the arrow. $\mathbf{b}$ Distribution of $\Theta$ values in the clastic and the single clast sample as a function of distance to the margin shown in 0.5 -mm bins. Mean value of the distal rhyolite and standard deviation are indicated for comparison. c Relative frequency of $\Theta$ values in the two whole proximal samples (clastic and single clast sample) and the distal rhyolite (distal rhyolite values are measured with respect to an arbitrary plane) shown in $10^{\circ}$ bins
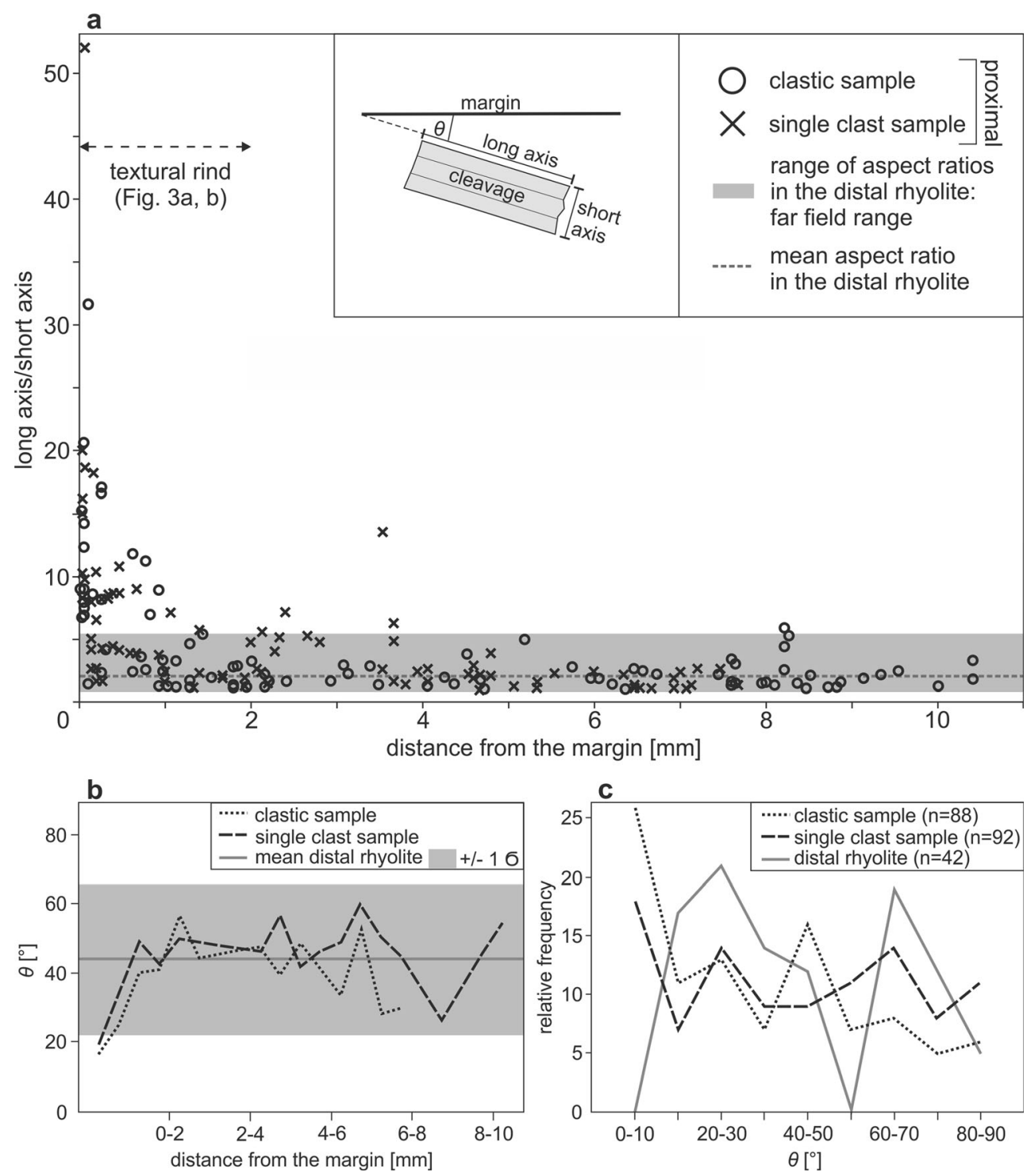

glass or liquid of $\rho=2,350 \mathrm{~kg} \cdot \mathrm{m}^{-3}$ and $C=1,000 \mathrm{~J} \cdot \mathrm{kg}^{-1} \cdot \mathrm{K}^{-1}$. The density and heat capacity of the atmosphere is taken to be $\rho^{\prime}=1.275 \mathrm{~kg} \cdot \mathrm{m}^{-3}$ and $C^{\prime}=1,007 \mathrm{~J} \cdot \mathrm{kg}^{-1} \cdot \mathrm{K}^{-1}$ (Lavallée et al. 2015). If we assume that initially the country rock is in thermal equilibrium at $T_{i}$ (here taken to be $\sim 20^{\circ} \mathrm{C}$ ), the initial condition can be described as follows:

$T=T_{i}$ for all values of $x$ at $t=0$.

At the rhyolite-basalt interface, we assume a constant wall temperature $T_{w}$ (constant Dirichlet boundary condition) of

$T=T_{w}$ for $t>0$ at $x=0$,

And in the far field (i.e. $x \rightarrow \infty$ ), we assume that the boundary is insulated (Neumann boundary condition of 0 )

$\frac{\partial T}{\partial x}=0$ for $t>0$ at $x=L$, where $L$ is some depth into the country rock which represents the far field.

By solving Eq. 1 numerically using a finite difference explicit forward-time, central-space scheme, we have the tools necessary to model the evolution of temperature in rhyolite country rock with any changing temperature at the margin.

We now use this model to assess the feasibility of heating the conduit wall by the advective passing of hot material inside the conduit during an eruption of similar duration as the 1886 Tarawera event. Explicit assumptions here are that: (1) the conduit margin is stationary such that no spalling or erosion of the margin occurs on the timescale of model/eruption and (2) any deformation of the margin is small such that translation of high or low porosity regions is not considered. We provide in Fig. 9a the solution to Eq. 1 for which the boundary temperature was the constant value required to reach a glass 


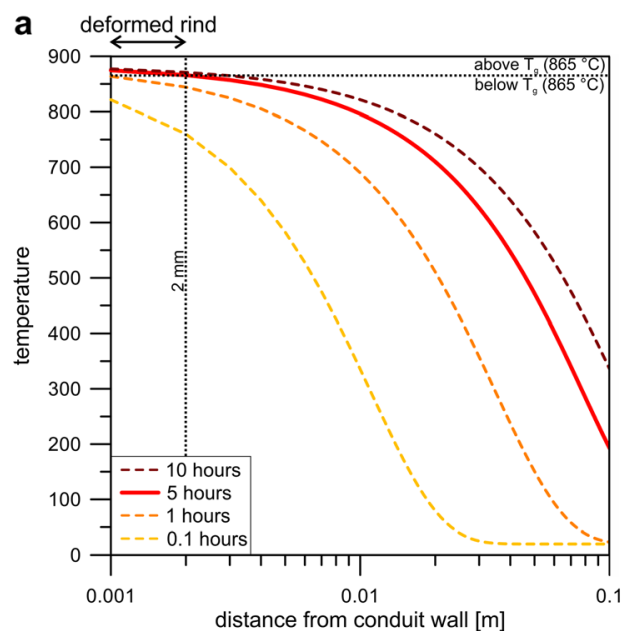

Fig. 9 a Temperature profiles in the wall rock at a constant boundary temperature condition for 10, 5, 1 and $0.1 \mathrm{~h}$, at a porosity of $\phi=0.5$ and a dissolved water content of $0.01 \mathrm{wt} . \%$. The glass transition temperature $T_{\mathrm{g}}$ of $\sim 865^{\circ} \mathrm{C}$ is approximated by a melt viscosity of $10^{11.4} \mathrm{~Pa} \cdot \mathrm{s}$ using Hess and Dingwell (1996). The thickness of the textural rind of $\sim 2 \mathrm{~mm}$ is highlighted. The timescale of the AD 1886 eruption of $\sim 5 \mathrm{~h}$ is sufficient to heat the thickness of the textural rind above its glass transition when the boundary temperature is $880^{\circ} \mathrm{C}$. b Time available for heat transfer into

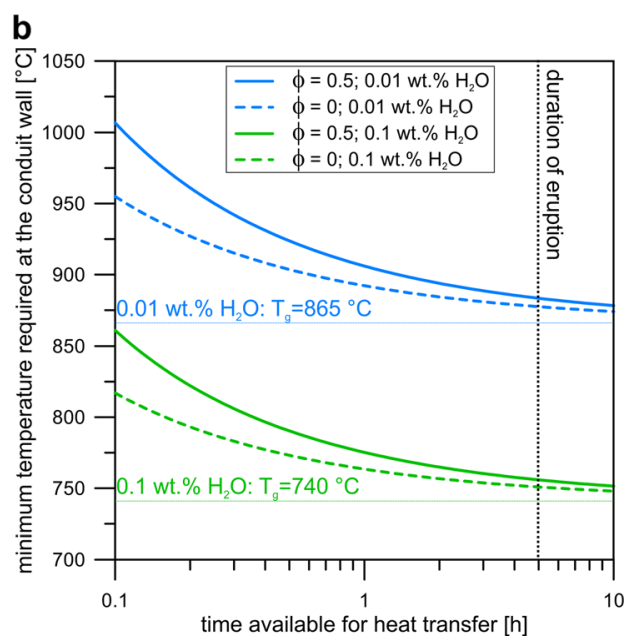

the wall rock as a function of the minimum required temperature at the conduit wall to heat the textural rind $(\sim 2 \mathrm{~mm})$ to the glass transition temperature. Solutions are for dissolved water contents of $0.1 \mathrm{wt} \%$ $\left(T_{\mathrm{g}}=\sim 740{ }^{\circ} \mathrm{C}\right)$ and $0.01 \mathrm{wt} \%\left(T_{\mathrm{g}}=\sim 865^{\circ} \mathrm{C}\right)$ and porosities of $\phi=0.5$ and $\phi=0$. Eruption timescale of $\sim 5 \mathrm{~h}$ is highlighted. In all scenarios, the temperature at the dyke interface is lower than typical basaltic eruptive temperatures

uppermost conduit. This result is consistent with estimates of margin temperature minima of $800{ }^{\circ} \mathrm{C}$ from Kennedy et al. (2010).

We conclude that this simple heat transfer consideration coupled with the textural observations provide tantalizing evidence that reheating and remelting of the conduit margin and that this could well have involved deformation above the glass transition and that indeed this process is physically feasible.

\section{Interpretation and discussion}

\section{Wall rock textures: the distal to proximal facies}

To interpret the textural evolution of the deformed rhyolite rind, it is critical to distinguish between textures in the rhyolite which are likely to be related to dome-forming processes during the $\sim \mathrm{AD} 1315$ Kaharoa eruption and those formed during reheating and subsequent deformation at the conduit wall associated with the AD 1886 Plinian basaltic eruption. Domeforming processes can impart a wide range of textures and such extrusion and emplacement textures have been reproduced experimentally, including bubble coalescence textures (e.g. dimple vesicle wall textures; Castro et al. 2012b), bubble collapse textures (Westrich and Eichelberger 1994; Kennedy et al. 2010) and bubble deformation textures (e.g. Rust and Manga 2002). In the Wahanga dome itself, vesicle orientation is highly variable and vesicles are always contorted and elongate (Ashwell 2013; Ashwell et al. 2015), and so may well be preserving the cooler portion of the 
as is typical for moderately porous volcanic domes (Manley and Fink 1987). Local flow complexities and local heterogeneities in groundmass vesicularity are attributable to strain localisation (Okumura et al. 2008; Wright and Weinberg 2009; Laumonier et al. 2011). Here, crystals in the distal sample have no preferred orientation (see "Distal rhyolite wall rock" section), and there is no preserved evidence for post dome emplacement deformation as described in section "Proximal rhyolite wall rock".

In the vicinity of the basaltic conduit, the textures stand in stark contrast to that of the distal rhyolite, including evidence for phenocryst fractures, biotite deformation, secondary vesiculation and bubble collapse (see "Proximal rhyolite wall rock" section). We ascribe the textural difference to the high temperatures and stresses imposed by the erupting column on the rhyolitic conduit walls, which work in concert to generate strain in the conduit wall. The temperature of a basaltic eruption mixture exceeds the glass transition temperature of rhyolite and the juxtaposition of a large flux of hot basaltic granular magma and volcanic gases with the glassy rhyolitic dyke wall upon eruption therefore has the capacity to thermally remobilize the rhyolite (see "The feasibility of reheating a conduit margin: a 1D solution to the heat equation" section). As the dyke was packed with hot basaltic pyroclasts after the eruption, temperatures above the rhyolite glass transition were likely maintained longer than the eruption timescale of $\sim 5 \mathrm{~h}$. The high proportion of groundmass glass in the rhyolite makes this initially solid phase thermally susceptible to "softening" and viscous deformation as the glass transition temperature is exceeded (Dingwell and Webb 1990). In the case of a sustained eruptive flow, the lateral heat transfer will result in a time-dependent temperature gradient in the marginal wall rock (Carrigan et al. 1992). Hence, the "penetration" distance from the margin within which the groundmass glass can be viscously remobilised increases with time (Kennedy et al. 2010). Furthermore, within a sufficient eruptive duration, the temperature of the rhyolitic conduit wall near the contact is expected to increase rapidly to temperatures approaching the basaltic eruptive temperature (Carrigan et al. 1992). The modified rhyolite rind records evidence of both brittle and viscous deformation. This behaviour is highlighted by brittle (cleaved and fractured) and minor crystal-plastic deformation in biotite phenocrysts, whereby the crystals exhibit both undulose extinction and bent cleavage. Crystal rotation resulting in stretched vesicles cannot occur without the groundmass glass first relaxing to a viscous liquid.

\section{Biotite deformation in the wall rock}

Within the deformed rhyolite rind, biotite crystals with their (001) cleavage approximately perpendicular to the margin show bending and fracturing textures, whereas biotite crystals with their (001) cleavage approximately parallel to the margin show cleavage steps and cleavage separation. Additionally, an accumulation of margin-parallel biotite crystals implies a rotation via flow. The maturity of these modifications increases with proximity to the margin, which is evidence for increasing shear strain (Kanaori et al. 1991). The calculated strain of 3.1 is a minimum because it is unlikely that a thin section suite captures a complete set of biotite fragments translated parallel to the margin. However, preparation of samples perpendicular to the strike of the dyke and parallel to the vertical flow direction optimises the possibility of accurately assessing strain. The absence of further deformation mechanisms in the rhyolite rind such as kink bands in the biotite crystals or recrystallized biotite grains - both of which are observed in cataclasites and mylonites (Bell 1979; Kanaori et al. 1991) - is here attributed to the short time-scale of the eruption. The short eruption time can also explain the absence of reaction rims in the textural rind and uniform chemical composition of the biotite crystals (ESM Fig. S1) in the proximal and the distal rhyolite.

\section{Vesiculation and diffusion}

Increasing vesiculation towards the margin, recording a heating above the glass transition temperature of the rhyolite groundmass glass, where oversaturated volatiles started to diffuse and vesicles form, is a natural consequence of higher temperatures near the margin. The vesiculation event at the margin observed in this study is confined to the deformed rhyolite rind at the dyke interface. The vesicles are round and only partially coalesced, suggesting little or no shear deformation was accommodated in this region after the vesiculation event. Vesiculation also caused brittle inflationary cracks in the accumulated ash layers. This implies that vesiculation in the rhyolite continued after accumulation of sintered basaltic ash along the dyke margin, because for the crack to form, the laminated and partly welded ash had to cool below the basalt solidus. Thus, we propose that, while it is possible that brittle and ductile deformation as well as vesiculation processes were coeval and in close spatial proximity to each other, vesiculation continued for a period of time after the cessation of the eruption.

\section{Implications of conduit wall sealing}

The thermal model reveals that the eruptive time of $\sim 5 \mathrm{~h}$ suffices to heat $2 \mathrm{~mm}$ of the rhyolitic wall rock, the thickness of the deformed rind, above the glass transition temperature. Given that the eruption duration represents a minimum time available for heat transfer and that the samples are from a shallow depth of $\sim 10 \mathrm{~m}$, we suggest that our proximal rhyolite samples only represent a minimum of conduit deformation which could be more pervasive at depth. We expect the thickness of the deformation zone and the temperatures reached to 
be an increasing function of depth in the conduit. Therefore, at greater depth the process of conduit wall sealing by viscous compaction, or of conduit wall vesiculation by pervasive reheating may be even more significant. Conduit margin deformation has implications for conduit permeability and outgassing (Rust et al. 2004; Kennedy et al. 2010), potential conduit wall sealing (e.g. Kennedy et al. 2010) and the explosivity of large eruptions (e.g. Jaupart and Allègre 1991). We highlight that conduit-wall sealing may not be the dominant mechanism for the explosivity of the AD 1886 Tarawera eruption and that phreatomagmatism is clearly a critical additional factor (e.g. Houghton et al. 2004). However, we use our observations from this locality to infer the importance of this process at depth in volcanic interiors for which the conduit wall rocks contain large fractions of glass, which is easily remobilized on re-heating.

\section{Concluding remarks}

Textural examination of a shallow feeder dyke reveals that the energetic AD 1886 basaltic Plinian eruption of Tarawera volcano caused reheating of the marginal wall rock such that (1) the groundmass glass softened to a viscously deformable liquid to form a 2-mm rhyolite rind at the dyke interface ("The feasibility of reheating a conduit margin: a 1D solution to the heat equation" section), (2) the groundmass is variably densified and vesiculated ("Micro-scale textures" section), (3) the biotite crystals in the rind are broken, rotated and deformed by viscous flow ("Micro-scale textures" section) and (4) brittle fractures occurred in the rhyolite wall rock ("Micro-scale textures" section). The data presented here highlight the pervasiveness of magma-rock interaction during explosive volcanic activity and its potential implications for magma degassing. Not measured here is the conduit wall permeability, for which significant changes in conduit wall porosity have implications. We conclude that a fruitful line of future inquiry would be to tie these textural constraints and the experimental constraints of Kennedy et al. (2010) with a suite of systematic measurements of permeability to assess whether conduit wall sealing may be a mechanism for preserving high overpressure required for large basaltic Plinian activity.

Acknowledgments We thank Paul Ashwell, Lauren Foote and Kirsty Herbert for field assistance and Ken Raureti and the members of the Ruawahia 2B Trust for access to Tarawera, and sampling permission. We are indebted to Elisabetta Mariani, Claudia Trepmann and Jonathan Castro for discussion about crystal deformation and Dirk Mueller for microprobe assistance. We thank the GJ Russell Microscopy Facility at Durham University for SEM support. We acknowledge funding from a starter grant from the Marsden Fund (09-UO-017C), the international science linkage funds from Royal Society of New Zealand (ISAT E613), the German Aerospace Centre (DLR) and Federal Ministry of Education and Research (BMBF; NZL 09/17), the European Union's seventh programme for research, technological development and demonstration under grant agreement no. 282759 (VUELCO), and from the European Research Council Starting Grant (SLiM, no. 306488) and Advanced Grant (EVOKES, no. 247076). We also thank Matt Edwards and GNS science for processing the DEM in Fig. 1. Comments from editors Thor Thordarsson and Michael Manga as well as reviewers Rebecca Carey, Hugh Tuffen, Colin Wilson and one anonymous expert greatly improved our work.

Open Access This article is distributed under the terms of the Creative Commons Attribution 4.0 International License (http:// creativecommons.org/licenses/by/4.0/), which permits unrestricted use, distribution, and reproduction in any medium, provided you give appropriate credit to the original author(s) and the source, provide a link to the Creative Commons license, and indicate if changes were made.

\section{References}

Allen SR, McPhie J (2003) Phenocryst fragments in rhyolitic lavas and lava domes. J Volcanol Geotherm Res 126(3):263-283

Ashwell PA (2013) Controls on rhyolite lava dome eruptions in the Taupo Volcanic Zone. PhD Thesis (unpublished) University of Canterbury, Christchurch, New Zealand

Ashwell PA, Kendrick JE, Lavallée Y, Kennedy BM, Hess K-U, von Aulock FW, Wadsworth FB, Vasseur J, Dingwell DB (2015) Permeability of compacting porous lavas. J Geophys Res Solid Earth 120(3):1605-1622

Bagdassarov NS, Dingwell DB (1994) Thermal properties of vesicular rhyolite. J Volcanol Geotherm Res 60(2):179-191

Bell TH (1979) The deformation and recrystallization of biotite in the Woodroffe Thrust mylonite zone. Tectonophysics 58(1-2):139-158

Carey RJ, Houghton BF, Sable JE, Wilson CJN (2007) Contrasting grain size and componentry in complex proximal deposits of the 1886 Tarawera basaltic Plinian eruption. Bull Volcanol 69(8):903-926

Carrigan CR, Schubert G, Eichelberger JC (1992) Thermal and dynamical regimes of single- and two-phase magmatic flow in dikes. Journal of Geophysical Research: Solid Earth (1978-2012) 97(B12):17377-17392

Castro JM, Cordonnier B, Tuffen H, Tobin MJ, Puskar L, Martin MC, Bechtel HA (2012a) The role of melt-fracture degassing in defusing explosive rhyolite eruptions at volcán Chaitén. Earth Planet Sci Lett 333:63-69

Castro JM, Burgisser A, Schipper CI, Mancini S (2012b) Mechanisms of bubble coalescence in silicic magmas. Bull Volcanol 74(10):2339 2352

Castro JM, Bindeman IN, Tuffen H, Schipper CI (2014) Explosive origin of silicic lava: textural and $\delta \mathrm{D}-\mathrm{H}_{2} \mathrm{O}$ evidence for pyroclastic degassing during rhyolite effusion. Earth Planet Sci Lett 405:52-61

Cole JW (1970a) Structure and eruptive history of the tarawera volcanic complex. N Z J Geol Geophys 13(4):879-902

Cole JW (1970b) Petrography of the rhyolite lavas of Tarawera Volcanic Complex. N Z J Geol Geophys 13(4):903-924

Connor CB, Lichtner PC, Conway FM, Hill BE, Ovsyannikov AA, Federchenko I, Doubik Y, Shapar VN, Taran YA (1997) Cooling of an igneous dike $20 \mathrm{yr}$ after intrusion. Geology 25(8):711-714

Cordonnier B, Caricchi L, Pistone M, Castro JM, Hess K-U, Gottschaller S, Manga M, Dingwell DB, Burlini L (2012) The viscous-brittle transition of crystal-bearing silicic melts: direct observation of magma rupture and healing. Geology 40(7):611-614

Costantini L, Houghton BF, Bonadonna C (2010) Constraints on eruption dynamics of basaltic explosive activity derived from chemical and 
microtextural study: the example of the Fontana Lapilli Plinian eruption, Nicaragua. J Volcanol Geotherm Res 189(3):207-224

Dingwell DB, Webb SL (1989) Structural relaxation in silicate melts and non-Newtonian melt rheology in geologic processes. Phys Chem Miner 16(5):508-516

Dingwell DB, Webb SL (1990) Relaxation in silicate melts. Eur J Mineral 4:427-449

Goepfert K, Gardner JE (2010) Influence of pre-eruptive storage conditions and volatile contents on explosive Plinian style eruptions of basic magma. Bull Volcanol 72(5):511-521

Heiken G, Wohletz K, Eichelberger J (1988) Fracture fillings and intrusive pyroclasts, Inyo domes, California. J Geophys Res Solid Earth 93(B5):4335-4350

Hess K-U, Dingwell DB (1996) Viscosities of leucogranitic melts: a nonArrhenian model. Am Mineral 81:1297-1300

Houghton BF, Gonnermann H (2008) Basaltic explosive volcanism: constraints from deposits and models. Chem Erde-Geochem 68(2):117-140

Houghton BF, Wilson CJN, Del Carlo P, Coltelli M, Sable JE, Carey RJ (2004) The influence of conduit processes on changes in style of basaltic Plinian eruptions: Tarawera 1886 and Etna 122 BC. J Volcanol Geotherm Res 137(1):1-14

Jaupart C (1998) Gas loss from magmas through conduit walls during eruption. In: Gilbert JS, Sparks RSJ (eds) The Physics of Explosive Volcanic Eruptions. Geological Society, London, Special Publications 145(1):73-90

Jaupart C, Allègre CJ (1991) Gas content, eruption rate and instabilities of eruption regime in silicic volcanoes. Earth Planet Sci Lett 102(3): 413-429

Kanaori Y, Kawakami S-I, Yairi K (1991) Microstructure of deformed biotite defining foliation in cataclasite zones in granite, central Japan. J Struct Geol 13(7):777-785

Kennedy BM, Spieler O, Scheu B, Kueppers U, Taddeucci J, Dingwell DB (2005) Conduit implosion during Vulcanian eruptions. Geology 33(7):581-584

Kennedy BM, Jellinek AM, Russell JK, Nichols ARL, Vigouroux N (2010) Time-and temperature-dependent conduit wall porosity: a key control on degassing and explosivity at Tarawera volcano, New Zealand. Earth Planet Sci Lett 299(1):126-137

Laumonier M, Arbaret L, Burgisser A, Champallier R (2011) Porosity redistribution enhanced by strain localization in crystal-rich magmas. Geology 39(8):715-718

Lavallée Y, Wadsworth FB, Vasseur J, Russell JK, Andrews GDM, Hess K-U, von Aulock FW, Kendrick JE, Tuffen H, Biggin AJ, Dingwell DB (2015) Eruption and emplacement timescales of ignimbrite super-eruptions from thermo-kinetics of glass shards. Frontiers in Earth Science 3(2)

Llewellin EW, Manga M (2005) Bubble suspension rheology and implications for conduit flow. J Volcanol Geotherm Res 143(1):205-217

Manga M, Castro J, Cashman KV, Loewenberg M (1998) Rheology of bubble-bearing magmas. J Volcanol Geotherm Res 87(1):15-28

Manley CR, Fink JH (1987) Internal textures of rhyolite flows as revealed by research drilling. Geology 15(6):549-552

Marzano FS, Lamantea M, Montopoli M, Herzog M, Graf H, Cimini D (2013) Microwave remote sensing of the 2011
Plinian eruption of the Grímsvötn Icelandic volcano. Remote Sens Environ 129:168-184

Nairn IA, Cole JW (1981) Basalt dikes in the 1886 Tarawera Rift. N Z J Geol Geophys 24(5-6):585-592

Nairn IA, Shane PR, Cole JW, Leonard GJ, Self S, Pearson N (2004) Rhyolite magma processes of the $\sim \mathrm{AD} 1315$ Kaharoa eruption episode, Tarawera volcano, New Zealand. J Volcanol Geotherm Res 131(3):265-294

Okumura S, Nakamura M, Tsuchiyama A, Nakano T, Uesugi K (2008) Evolution of bubble microstructure in sheared rhyolite: formation of a channel-like bubble network. J Geophys Res Solid Earth 113, B07208

Proussevitch AA, Sahagian DL (1996) Dynamics of coupled diffusive and decompressive bubble growth in magmatic systems. J Geophys Res Solid Earth 101(B8):17447-17455

Richnow J (1999) Eruptional and Post-eruptional Processes in Rhyolite Domes. PhD Thesis (unpublished). University of Canterbury, Christchurch, New Zealand,

Russell JK, Quane SL (2005) Rheology of welding: inversion of field constraints. J Volcanol Geotherm Res 142(1):173-191

Rust AC, Manga M (2002) Bubble shapes and orientations in low Re simple shear flow. J Colloid Interface Sci 249(2):476-480

Rust AC, Cashman KV, Wallace PJ (2004) Magma degassing buffered by vapor flow through brecciated conduit margins. Geology 32(4): 349-352

Sable JE, Houghton BF, Wilson CJN, Carey RJ (2006) Complex proximal sedimentation from Plinian plumes: the example of Tarawera 1886. Bull Volcanol 69(1):89-103

Sable JE, Houghton BF, Wilson CJN, Carey RJ (2009) Eruption mechanisms during the climax of the Tarawera 1886 basaltic Plinian eruption inferred from microtextural characteristics of the deposits. In: Thordarson T, Self S, Larsen G, Rowland SK, Hoskuldsson A (eds) Studies in Volcanology: The Legacy of George Walker. Special Publications of IAVCEI 2:129-154

Stasiuk MV, Barclay J, Carroll MR, Jaupart C, Ratté JC, Sparks RSJ, Tait SR (1996) Degassing during magma ascent in the Mule Creek vent (USA). Bull Volcanol 58(2-3):117-130

Thordarson T, Self S (2003) Atmospheric and environmental effects of the 1783-1784 Laki eruption: a review and reassessment. Journal of Geophysical Research: Atmospheres 108 (D1): AAC 7-1--AAC 7-29

Tuffen H, Dingwell DB, Pinkerton H (2003) Repeated fracture and healing of silicic magma generate flow banding and earthquakes? Geology 31(12):1089-1092

Walker GPL, Self S, Wilson L (1984) Tarawera 1886, New Zealand - a basaltic plinian fissure eruption. J Volcanol Geotherm Res 21(1):61-78

Westrich HR, Eichelberger JC (1994) Gas transport and bubble collapse in rhyolitic magma: an experimental approach. Bull Volcanol 56(67):447-458

Wright HMN, Weinberg RF (2009) Strain localization in vesicular magma: implications for rheology and fragmentation. Geology 37(11): $1023-1026$ 